\title{
Glyphosate on shikimic acid on Urochloa plantaginea
}

\author{
Sydnei Dionisio Batista de Almeida ${ }^{1}$ (D) Daniel Andrade de Siqueira Franco ${ }^{1}$ (D) \\ Antonio Luiz Cerdeira ${ }^{2}$ (D) Sonia Claudia do Nascimento de Queiroz ${ }^{2}$ (i) \\ Marcus Barifouse Matallo $^{1^{*}}$ (D)
}

${ }^{1}$ Centro Avançado de Pesquisa em Proteção de Plantas e Saúde Animal, Instituto Biológico, 13101-680, Campinas, SP, Brasil. E-mail: phyton sp@live.com.br. "Corresponding author.

${ }^{2}$ Embrapa Meio Ambiente, Jaguariúna, SP, Brasil.

ABSTRACT: Shikimic acid (SA) has witnessed a strong increase in recent years due to the increasing demand of the pharmaceutical and cosmetic industry. The $S A$ is used as a precursor for the synthesis of oseltamivir phosphate (Tamiflu ${ }^{\mathbb{R}}$ ), a potent viral inhibitor and is extracted from the plant Illicium verum Hook which has a limited availability. This article proposed the use of Urochloa plantaginea (Link.) webster and glyphosate, as an alternative source of SA. U. plantaginea plants with 3 - 4 tillers and $4-6$ leaves were harvest at 3, 6, 9 and 12 days after application (DAT) of low rates of glyphosate. Samples were dried, extracted, analyzed by HPLC and LC-MS/MS. The maximum SA concentrations were observed at 6 days after glyphosate at 36 g.a.e.ha ${ }^{-1}$ was applied in plants of U. plantaginea with 4 to 6 leaves. The capability of this annual gramineae to produce elevated SA levels throughout the entire biomass affords its potential for a greater yield on a per hectare basis.

Key words: oseltamivir phosphate, Influenza, Illicium verum, 5-enol pyruvyl shikimate-3-phosphate synthase (EPSPs), Brachiária plantaginea.

Efeito do glifosato no ácido chiquímico em Urochloa plantaginea

RESUMO: O interesse pelo ácido chiquímico (SA) tem apresentado um forte incremento nos últimos anos devido à crescente demanda da indústria farmacêutica e cosmética. O SA é utilizado como um precursor para a síntese do fosfato de oseltamivir (Tamiflu ${ }^{\circledR}$ ), um potente inibidor viral. Este ácido é extraído principalmente da planta Illicium verum Hook. A disponibilidade desta planta é um fator limitante para o crescimento do mercado no futuro próximo. Este artigo propõe Urochloa plantaginea (Link.) webster tratada com sub doses de glifosato, como uma fonte alternativa de SA. Plantas de U. plantaginea com 3 - 4 perfilhos e 4 a 6 folhas foram tratadas com subdoses de glifosato e coletadas aos 0, 3, 6, 9 e 12 dias após sua aplicação (DAT). As amostras foram secas, extraidas e analisadas por HPLC e confirmadas por LC-MS/MS. As concentrações máximas de SA foram observadas aos seis dias após aplicação do glifosato a 36 g.e.a.ha-1 em plantas de U. plantaginea com 4 - 6 folhas. A capacidade anual dessa gramínea para produzir niveis elevados de SA em toda a biomassa, pode ser uma fonte economicamente viável de $S A$.

Palavras-chave: fosfato de oseltamivir, Influenza, Anis estrelado, EPSPs, Brachiaria plantaginea.

\section{INTRODUCTION}

Shikimic acid (SA) has witnessed a strong demand in recent years due to the increasing use in the pharmaceutical and cosmetic industry as a chiral binding block for the synthesis of a wide range of products (QUIROZ et al, 2014). The growing demand for cosmetic products, especially by the female population, coupled with technological advances in the pharmaceutical industry, is expected to increase. Shikimic acid is used as a precursor for the synthesis of oseltamivir phosphate $\left(\right.$ Tamiflu $\left.^{\circledR}\right)$, a potent viral inhibitor, the only drug to combat bird flu (SHIBASAKI et. al., 2011). The focus on SA has increased in recent years due to the increasing number of flu victims worldwide (BORAH, 2015). This acid 
is also used in the synthesis of biologically based products, including aromatic amino acids (RAWAT et al., 2013). The increased demand for oseltamivir phosphate from the agricultural sector is the key factor in boosting demand for SA for the coming years. This acid is mainly extracted from the plant $I$. verum, and the limited availability of this plant is expected to prevent market growth in the near future (FARINA \& BROWN, 2006). The SA content in the plants varies according to the vegetable source and the harvest season and other factors (GHOSH et al., 2012).

The transition from traditional agriculture with low impact practices to intensive pesticidebased agriculture has influenced farming systems and the introduction of the glyphosate (N-(fosfonometil) glicina) herbicide was the milestone of a new age in control of weeds (HELANDER et al., 2012). Glyphosate inhibits the enzyme 5-enol pyruvyl shikimate-3-phosphate synthesis (EPSPs), with consequent accumulation of SA in plants and microorganisms (ANDERSON et al, 2001; FRANCO et al, 2012). The extent of accumulation of SA in response to inhibition of EPSPs by glyphosate, in addition to determining plant exposure to this herbicide, has been used as a quick and accurate way to identify resistant weeds (MUELLER et al, 2003). In a transient period, the accumulation of SA has been reported to occur one day after application of glyphosate, reaching peaks of concentration between 4 and 7 days after, or more (KOGER et al., 2005).

Originally from Africa, U. plantaginea, Poacea family, is a grassy annual cycle, common in Brazil, where it grows for green forage, producing a rapid spring growth, high nutritional value allowing up to three cuts per cycle (VELHO et al, 2012). Its phenotypic characteristics, combined with the edaphoclimatic requirements, allow its cultivation practically all over the Brazil territory.

Based on hypothesis of that $U$. plantaginea will be a good source of SA after treated with glyphosate associated with your geographic distribution, as well as its ease of cultivation and low maintenance cost, the objective of this research was to verify the production of in plants of $U$. plantaginea induced by application of low rate of glyphosate as a potential technique in producing a precursor for synthesis of oseltamivir phosphate.

\section{MATERIALS AND METHODS}

Seeds of $U$. plantaginea were sown in two liter pots kept in greenhouse and irrigated automatically by spraying. After emergence, thinning was done, leaving five seedlings per pot. When the plants reached 3 - 4 tillers (Growth Stage 1 -GS1) and $4-6$ leaves (GS 2) the treatments with glyphosate at $0.00,0.36,3.60$ and 36.00 g. a.e.ha ${ }^{-1}$ were applied by means of a constant pressure backpack sprayer $\left(\mathrm{CO}_{2}\right)$, equipped with tips 80.02 , pressure of $40 \mathrm{lb}^{\mathrm{b}} \mathrm{pol}^{-2}$ and consumption of $100 \mathrm{~L} \mathrm{ha}^{-1}$ of solution.

The experiments were conducted at Campinas, São Paulo, Brazil (22 54 507' S and $47^{\circ} 1{ }^{\prime} 029^{\prime}$ W). Prior spraying and 3, 6, 9 and 12 days after (DAT), all epigeal parts of the plants were harvested and oven dried at $60{ }^{\circ} \mathrm{C}$ for 3 days, milled at 25,000 rpm (IKA 25 Basic) and immediately kept in a freezer at $-10{ }^{\circ} \mathrm{C}$. Basically, the extraction of SA was performed according to the method developed by MATALLO et. al. (2009). $100 \mathrm{mg}$ sub-samples were weighed and then added $5 \mathrm{~mL}$ of acidified distilled water with phosphoric acid at $\mathrm{pH}$ 2.0. The extraction was carried out in microwave oven (Panasonic model NN-S62B) at100 W for 10 seconds; then the samples were filtered through Whatmann no.1 filter paper and Milli-GV, Millipore, $0.22 \mu \mathrm{m}$ membrane filter and analyzed by LC-MS/MS.

The SA concentration in the samples was determined by using a liquid chromatograph (Shimadzu LC 2010A), at the wavelength of 212.0 $\mathrm{nm}$. The employed column was Phenomenex brand, model Gemini C18 (250.0 mm x $4.0 \mathrm{~mm}, 5.0 \mu \mathrm{m}$ particle size) with pre-column $\mathrm{C}_{18}$ of the same brand. The injection volume used was $20.0 \mu \mathrm{L}$. The isocratic system utilized as the mobile phase the MilliQ water mixture at $\mathrm{pH}$ 3.0: Methanol (HPLC grade) in the ratio 95: 5 and flow of $1.0 \mathrm{~mL}$.minute ${ }^{-1}$. The confirmation of the SA was carried out in a Liquid Chromatograph - UFLC - Shimadzu coupled to the Bruker Daltonics mass spectrometer - Amazon Model X - Type Ion Trap with ionization source - Electrospray (ESI) under the following conditions: UFLC Modules: Auto Sampler: SIL - 20 AC; Column oven: CTO20; Communications Bus Module: CBM-20a; Pumps: LC-20AT; Degasser: DGU-20As, Column - Lichrosorb-RP-18 - 100A, 250 x 4.60mm - $5 \mu \mathrm{m}$ Phenomenex; Security Guard cartridges - Fusion - RP - 4 x 3.0mm - phenomenex; Injection volume - 20

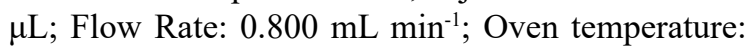
$40{ }^{\circ} \mathrm{C}$; Mobile Phase: Isocratic: $10 \%$ Methanol HPLC Grade: 90\% Ammonium Acetate; Running Time: 7 minutes. The mass spectrometer was operated in MS mode with electrospray ionization in the negative ion mode. The capillary voltage was optimized at -4500 $\mathrm{V}$. The nitrogen was used as nebulization gas at 320 ${ }^{\circ} \mathrm{C}$ with a flow of $10 \mathrm{~L} \mathrm{~min}^{-1}$ and a pressure of $60 \mathrm{psi}$. Helium was used as a collision gas. 
The experiment was conducted in the $4 \times 4 \times 2$ factorial scheme, combining the factors glyphosate rates (4) and leaves collection times (LCT) (4), and different stages of growth (SG) (2). The experimental design was a completely randomized. Data were analyzed by the $\mathrm{F}$ test and adjusted to a exponential model $Y=a$. $e^{b x}$ where $Y$ is the shikimic acid concentration at each glyphosate rate, $a$ the inicial rate of glyphosate, $b$ the rate of change in the SA concentration and $x$, the LCT When necessary the comparisons between treatments was made by the Tukey test $(p \leq 0.05)$, using the ASSISTAT program.

\section{RESULTS AND DISCUSSION}

An analytical curve with SA with concentrations ranging from 2.04 to $407.2 \mu \mathrm{g} . \mathrm{mg}^{-1}$ was constructed for quantifying SA concentrations. The relationship between the concentrations and the areas of the chromatographic peaks was linear with correlation coefficient $(\mathrm{R})$ of 0.9999 . The detection limit of the method was $0.395 \mu \mathrm{g} . \mathrm{mg}^{-1}$, the limit of quantification of the method was $2.04 \mu \mathrm{g} . \mathrm{mg}^{-1}$ (the lower point of the curve) and total run time was 10 minutes.

In order to confirm the presence of SA in the samples the Liquid Chromatography coupled to Mass Spectrometry was used. In this instrument, the retention time was $3.2 \mathrm{~min}$. and quantification fragment $m / z$ 172.7. SA was identified on the basis of the retention time and the mass spectra of the chromatographic peak by comparison with the retention time and the mass spectra of commercial standard. The standard exhibits a peak at 3.2 minutes and it's mass spectra had a [M-H $]^{-}$ion at $m / z$ 172.6, with is in according to $\mathrm{C}_{7} \mathrm{H}_{10} \mathrm{O}_{5}$. Confirmed also by spiking the standard into the extract, the peak at 3.2 minutes and its mass spectra had a $[\mathrm{M}-\mathrm{H}]^{-}$ion at $\mathrm{m} / \mathrm{z}$ 172.7. The retention time of SA was reported normally to be in the range of 3.0 to 5.5 minutes (ENRICH et al., 2008; CARDOSO et al 2014; MATALLO et al., 2014; BECERRA-MORENO et al., (2012); although, depending on methodology, it could be longer like 19,8 $\min$ (SUI, 2008).

Other strategies have been developed for extraction of SA in different matrices like Ginkgo biloba leaves (USUKI et al, 2011). A fast and low cost method employing SA extraction from $I$. verum using pressurized hot water (PHWE) with an espresso coffee machine was developed by JUST et al (2015). More recently, COSTA et al. (2016), combining near infrared spectroscopy and multivariate analysis using partial least squares regression, quantified the accumulation of SA in U. plantaginea.
The results showed an exponential growth of the SA concentration in the leaves of $U$. plantaginea with glyphosate at all rates (Figure 1). At 3 DAT in both growth stages (SG1 and SG2) a higher rate of increase in SA level was observed (Figure 1A). This accumulation continues to raise reaching a peak at 6 DAT (Figure 1B), with the later sprayed plants (SG2) showing the highest rate of change in SA concentration throughout the experiment $\left(b=0.04305 \mathrm{mg} \cdot \mathrm{kg}^{-1}\right)$. After that, a drop in the concentration for both growth stages was observed, especially when glyphosate was applied at the initial stage (3-4 tillers), with a limitability of elevation at 12 DAT in the plants treated with the herbicide at the SG2 stage (Figure 1C and D).

Comparing the treatments at the peak of SA accumulation (6 DAT), significant increase in concentration of SA in SG2 was observed when glyphosate was applied at $36 \mathrm{~g}$. a.e ha ${ }^{-1}$ representing SA levels increased by 4.45 fold when compared with non-treated plants over time (Table 1).

Despite the efforts of the research to obtain SA from other sources such as production from recombining microorganisms such as $E$. coli (GHOSH et al., 2012), the major source are extracted from plants, specially Chinese star anise, which grows primarily in a limited region of China and Vietnam, a long time consuming period to production (WANG et al., 2011).

The increase in the SA concentrations observed in this study are in agreement with HOBBIE et al. (2017), in which glyphosate-susceptible forage crops can be biologically enhanced via glyphosate application to produce a reliable feedstock for SA markets. Depending on the rate and the environmental conditions the maximum of SA level can be reached between 96 to $196 \mathrm{~h}$ after glyphosate application at levels up to four-fold in glyphosate-treated Gulf annual ryegrass. The overall mean SA content at the highest peak over all treatments at 6 DAT was $31.88 \%(\mathrm{w} / \mathrm{w})$, a value much higher than the range found by RAGHAVENDRA et al. (2009) screening 193 trees species, and shortlisted seven angiosperms that contained $0.17 \%$ of SA $(\mathrm{w} / \mathrm{w})$ without glyphosate application.

The highest significantly treatment observed (36.00 a.i.ha ${ }^{-1} / \mathrm{SG} 2 / 6$ DAT) was used to estimate the potential SA yield from crop biomass on a per-hectare basis. Forage crops such as $U$. plantaginea used in this study, could yield 3.5 to 7.5 t.ha ${ }^{-1}$ of dry matter depending on planting density, environmental conditions and forage management (VELHO et al., 2012), it could produce approximately 

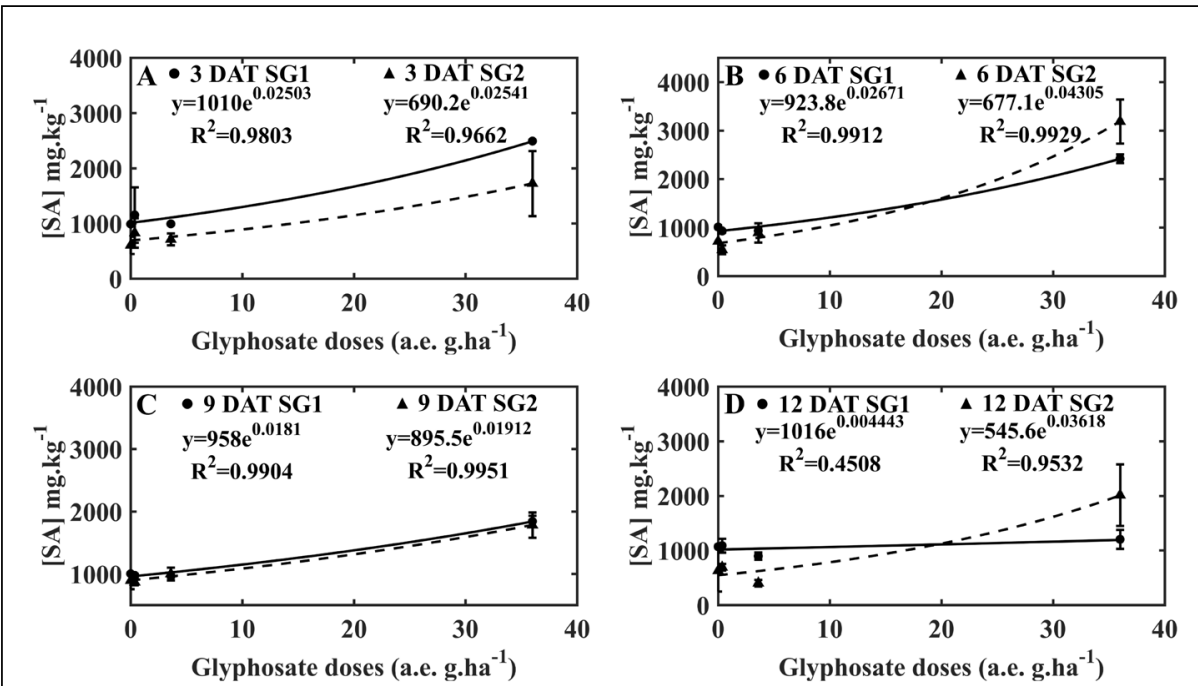

Figure 1 - SA accumulation at 3 (A), 6 (B), 9 (C) and 12 (D) days after application of low doses of glyphosate in $U$. plantaginea at 3-4 tillers (SG1) and 4-6 leaves (SG2).

$24.0 \mathrm{~kg} \cdot \mathrm{ha}^{-1}$ of SA (gross production). Considering that $U$. plantaginea is $i$ ) an angiosperm with $\mathrm{C} 4$ photosynthesis, $i$ ) rapidly yield large estimated mass and with a wide distribution throughout the Brazilian territory, iii) a grass with high dry mass production, $i v$ ) adapted to a wide range of soil types, with well distributed growth during most of the year, and $v$ ) provided that the formation of seeds is allowed, this forage is renewed annually there potentially advantage in producing this forage for SA feedstock.

Applying the same estimates, HOBBIE et al. (2017) estimated that alfalfa treated with glyphosate bio enhanced the SA production from 31.5 to $299 \mathrm{~kg} \cdot \mathrm{ha}^{-1}$ as compared with Chinese star anise, that could produce 14 to $18 \mathrm{~kg} \cdot \mathrm{ha}^{-1}$ of SA from dried fruit (FARINA \& BROWN,.., 2006) maturity over $60 \mathrm{wk}$, with only annual fruit production (WANG et al., 2011). The overall profitability to the producer would need to be explored in further detail, as cost of planting, harvest yield, processing and extraction efficiency (HOBIE et al. (2017).

The present study confirmed that SA accumulates by low rates of glyphosate applied to forage crops generating a feedstock of this acid at a commercial scale, specially due to the wide distribution and relatively non-specific growing requirements as compared with other plant sources of SA. Future studies are required to extrapolate

Table 1 - Shikimic acid content $\left(\mathrm{mg} \cdot \mathrm{kg}^{-1}\right)$ and ratio to the untreated plants at different times after low rates of glyphosate applied in U.plantaginea at 4-6 leaves (SG2).

\begin{tabular}{lcccccccc}
\hline Rates & $3 \mathrm{DAT}$ & ratio & $6 \mathrm{DAT}$ & ratio & $9 \mathrm{DAT}$ & ratio & $12 \mathrm{DAT}$ & ratio \\
\hline 0.00 & $604.2 \mathrm{aA}$ & 1.00 & $717.2 \mathrm{aA}$ & 1.00 & $892.1 \mathrm{aA}$ & 1.00 & $629.4 \mathrm{aA}$ & 1.00 \\
0.36 & $827.7 \mathrm{aA}$ & 1.34 & $541.9 \mathrm{aA}$ & 0.76 & $867.1 \mathrm{aA}$ & 0.97 & $693.1 \mathrm{aA}$ & 1.10 \\
3.60 & $710.7 \mathrm{aA}$ & 1.18 & $892.1 \mathrm{aA}$ & 1.24 & $998.7 \mathrm{aA}$ & 1.12 & $402.4 \mathrm{aB}$ & 0.64 \\
36.00 & $1724.4 \mathrm{bB}$ & 2.85 & $3187.9 \mathrm{bA}$ & 4.45 & $1780.5 \mathrm{bB}$ & 1.99 & $2013.2 \mathrm{bB}$ & 3.20 \\
\hline
\end{tabular}

Means followed by same letter (lowercase) in each column and uppercase in each row do not differ significantly (P<0.05 ) by Tukey test. DAT=Days After Treatment, Rates $=\left(\mathrm{g}\right.$ a.e. $\left.\mathrm{ha}^{-1}\right)$, grams of acid equivalent per hectare. 
our results to the industrial level and investigate impacts on environment, forage and crops yield. $U$. plantaginea can be an economically viable source of SA and may contribute to the increase availability of this acid at market.

\section{ACKNOWLEDGEMENTS}

This work was carried out with the support and funding of $\mathrm{CNPq}$, Conselho Nacional de Desenvolvimento Científico e Tecnológico - Brasil Project n ${ }^{\circ}$ 471927/2013-9 and Coordenação de Aperfeiçoamento de Pessoal de Nível Superior (CAPES), Brasil - Finance code 001. JLNM and GBS have scholarships from $\mathrm{CNPq}$ and ANS from CAPES.

\section{DECLARATION OF CONFLICT OF INTERESTS}

The authors declare no conflict of interest. The founding sponsors had no role in the design of the study; in the collection, analyses, or interpretation of data; in the writing of the manuscript, and in the decision to publish the results.

\section{AUTHORS' CONTRIBUTIONS}

The authors contributed equally to the manuscript.

\section{REFERENCES}

ANDERSON, K. A. et. al. Analytical method for determination of shikimic acid: Shikimic acid proportional to glyphosate application rates, Commun. Soil Sci. Plant Anal., v.32, n.17/18, p.2831-40, 2001. Available from: <https://www.tandfonline.com/ doi/abs/10.1081/CSS-120000965>. Accessed: Aug. 14, 2018. doi: $10.1081 /$ CSS-120000965.

BECERRA-MORENO, A. et al. Plants as biofactories: glyphosate-induced production of shikimic acid and phenolic antioxidants in wounded carrot tissue. J. Agric. Food Chem. v.60, p.11378-386, 2012. Available from: <https://pubs.acs. org/doi/10.1021/jf303252v>. Accessed: Aug. 16, 2018. doi: $10.1021 / \mathrm{jf} 303252 \mathrm{v}$

BORAH, J. C. Shikimic acid: a highly prospective molecule in pharmaceutical industry. Curr. Sci., v.109, n.9, 2015. Available from: <https://web.a.ebscohost.com/abstract?dire $\mathrm{ct}=$ true \& profile $=$ ehost $\&$ scope $=$ site $\&$ authtype $=$ crawler $\&$ jrnl $=00113891 \& \mathrm{AN}=111318210 \& \mathrm{~h}=8 \mathrm{~T} 0 \mathrm{VuA} 94 \mathrm{mMNExHV} \% 2$ ftL $\% 2$ fY\%2fqK0Px08d\%2fHIosX78pp9mdI8g7tD8TDMTX kIHGNDB10K2v8d48j1LAP0eQs8F39gQA\%3d\%3d\&crl=c\& resultNs $=$ AdminWebAuth\&resultLocal=ErrCrlNotAuth\&crl hashurl $=$ login.aspx $\% 3$ fdirect $\% 3$ dtrue $\% 26$ profile $\% 3$ dehost $\%$ 26scope\%3dsite\%26authtype\%3dcrawler\%26jrnl\%3d00113 891\%26AN\%3d111318210>. Accessed: Aug. 23, 2018. doi: 10.18520/v109/i9/1672-1679.

CARDOSO, S. F. et al. Eichornia crassipes: an advantageous source of shikimic acid. Rev. Bras. Farmacogn., v.24, p.439-442, 2014. Available from: <https://www.sciencedirect.com/science/ article/pii/S0102695X14000568?via\%3Dihub>. Accessed: Sep. 09, 2018. doi: 10.1016/j.bjp.2014.08.003.
COSTA, M. C. A. et al. Brachiaria plantaginea as a potential (new) source of shikimic acid.quantification by NIR and PLS regression. Plant Med. Lett., v.3, n.04 p.e81-e84, 2016. Available from: $<$ https://www.thieme-connect.com/products/ejournals/abstract/10 $.1055 / \mathrm{s}-0042-102202>$. Accessed: Sep. 11, 2018. doi: 10.1055/s0042-102202.

ENRICH, L. B. et. al. Liquidambar styraciflua: a renewable source of shikimic acid. Tetrahedron Lett., v.49, p.25032505, 2008. Available from: <https://arizona.pure.elsevier.com/ en/publications/liquidambar-styraciflua-a-renewable-sourceof-shikimic-acid $>$. Accessed: Sep. 13, 2018. doi: 10.1016/j. tetlet.2008.02.140.

FARINA, V.; BROWN, J. D. Tamiflu: The supply problem. Angew Chem Int., v.45, p.7330-7334. 2006. Available from: <https:// onlinelibrary.wiley.com/doi/abs/10.1002/anie.200602623>. Accessed: Sep. 19, 2018. doi: 10.1002/anie.200602623.

FRANCO, D. A. S. et al. Evaluation of glyphosate application on transgenic soybean and it's relationship with shikimic acid. Planta Daninha, v.30, n.3, p.659-666, 2012. Available from: $<$ https://www.scielo.br/scielo.php?script=sci_arttext\&pid $=$ S0100-83582012000300023 $>$. Accessed: Sep. 22, 2018. doi: $10.1590 / \mathrm{S} 0100-83582012000300023$.

GHOSH, S. et al. Production of shikimic acid. Biotechnol Adv. v.30, p.1425-31, 2012. Available from: $<$ https://pubmed.ncbi.nlm. nih.gov/22445787/>. Accessed: Sep. 25, 2018. doi: 10.1016/j. biotechadv.2012.03.001.

HELANDER, M. et al. Glyphosate in northern ecosystems. Trends Plant Sci., v. 17, n. 10, p. 569-574, 2012. Available from: $<$ https://www.cell.com/trends/plant-science/fulltext/S13601385(12)00107-0? returnURL=https\%3A\%2F\%2Flinkinghub. elsevier.com $\% 2$ Fretrieve $\% 2$ Fpii $\% 2$ FS $1360138512001070 \% 3$ Fshowall\%3Dtrue $>$. Accessed: Sep. 26, 2018. doi: 10.1016/j. tplants.2012.05.008.

HOBBIE, K. et al. An alternative method to produce shikimic acid: Chemical feedstock by applying glyphosate to forage crops. Crop Sci., v.57, p.945-950, 2017. Available from: $<$ https://acsess. onlinelibrary.wiley.com/doi/full/10.2135/cropsci2016.11.0921>. Accessed: Oct. 08, 2018. doi: 10.2135/cropsci2016.11.0921.

KOGER, C. et al. Rice (Oryza sativa) response to drift rates of glyphosate. Pest Manage. Sci., v.61, p.1161-67, 2005. Available from: < https://pubmed.ncbi.nlm.nih.gov/16189844/>. Accessed: Oct. 17, 2018. doi: 10.1002/ps.1113.

JUST, J. et al. A new method for the rapid extraction of natural products: efficient isolation of shikimic acid from star anise. Org Lett., v.17, n.10, p.2428-2430, 2015. Available from: <https:// pubs.acs.org/doi/10.1021/acs.orglett.5b00936>. Accessed: Oct. 15, 2018. doi: 10.1021/acs.orglett.5b00936.

MATALLO, M. B. et al. Glyphosate as a tool to produce shikimic acid in plants. Planta Daninha, v.32, n.3, p.601-08, 2014. Available from: $<$ https://www.scielo.br/scielo.php?script=sci_artt ext\&pid=S0100-83582014000300016>. Accessed: Oct. 27, 2018. doi: $10.1590 / \mathrm{S} 0100-83582014000300016$.

MATALLO, M. B. et al. Microwave-assited solvent extraction of shikimic acid from plant tissues. Planta Daninha, 
v.27, p.987-94, 2009, Suplemento 4. Available from: $<$ https://www.scielo.br/scielo.php?script=sci arttext\&pid $=\mathrm{S} 0100-83582009000500012>$. Accessed: Nov. 02, 2018. doi: $10.1590 / \mathrm{S} 0100-83582009000500012$.

MUELLER, T. C. et al. Shikimate accumulates in both glyphosate-sensitive and glyphosate-resistant horseweed (Conyza canadensis L. Cronq.), J. Agric. Food Chem., v.51, p.680-84, 2003. Available from: <https://pubs.acs.org/ doi/abs/10.1021/jf026006k>. Accessed: Nov. 10, 2018. doi: $10.1021 / \mathrm{jf0} 26006 \mathrm{k}$.

QUIROZ, D. C. D. et al. Current perspectives on applications of shikimic acid and aminoshikimic acids in pharmaceutical chemistry. Res. Rep. Med. Chem., v.4, p.35-46, 2014. Available from: <https:// www.dovepress.com/current-perspectives-on-applications-ofshikimic-and-aminoshikimic-aci-peer-reviewed-article-RRMC $>$. Accessed: Nov. 12, 2018. doi: 10.2147/RRMC.S46560.

RAGHAVENDRA, R. et al. Prospecting for alternate sources of shikimic acid, a precursor of Tamiflu, a bird -flu drug. Curr. Sci., v.96, n.6, p.771-72, 2009. Available from: <http://eprints.iisc. ac.in/26104/1/771.pdf>. Accessed: Nov. 18, 2018.

RAWAT, G. et al. Expanding horizons of shikimic acid. Recent progresses in production and its endless frontiers in application and marketing trends. Appl. Microbiol. Biotechnol., v.97, p. 4277-4287, 2013. Available from: <https://link.springer.com/ article/10.1007/s00253-013-4840-y>. Accessed: Nov. 20, 2018. doi: 10.1007/s00253-013-4840-y. 